\title{
Economic Regulation of the Municipal Property Utilization in the Territories
}

\author{
Irina Vladimirovna Andronova' and Nadezhda Pavlovna Deberdieva ${ }^{2 *}$
}

\author{
${ }^{1}$ LUKOIL-Engineering, LLC, Moscow, Russian Federation \\ ${ }^{2}$ Tyumen State Oil and Gas University, Tyumen, Russian Federation; \\ dnp1803@mail.ru
}

\begin{abstract}
This paper discusses the organizational and methodological guidelines for economic regulation of the municipal property complex utilization. We have redefined and updated the classification of municipal assets as the elements of a sophisticated multi-component structure, comprising property located within the municipal territory. We have justified the targeted managerial decisions to encourage the efficient property utilization at different stages of its life cycle. We have defined the conceptual aspects of economic regulation as a state administration function within the competence of municipality. We have summarized and systematized the theoretical and methodological approaches to economic regulation of municipal property complex utilization in Russia. We have identified the problems, precluding the efficient property complex utilization based on the redefined and updated principles of economic regulation. We have presented the recommendations for a comprehensive evaluation of the municipal property utilization, considering social, economic and financial effectiveness. We have surveyed the scientific papers and publications, addressing the issues of municipal property utilization efficiency, economic regulation and other research literature. We have concluded about the necessity for further study of the effective regulatory mechanisms for municipal property utilization to enhance the strategic municipality development.
\end{abstract}

Keywords: Economic Regulation, Municipality, Municipal Property, Property Value

\section{Introduction}

An increasing awareness of the institutional structure's role in stable social and economic development of regions and municipalities sets the new examination and evaluation trends for economic regulation of the municipal property complex utilization, where the effectiveness depends on target development indicators of the territory and demand for its resources.

Economic changes in Russia had fundamentally changed the property relations that entailed the need to analyze the ongoing process of municipal property function from a standpoint of its effective use. Insufficiently rational use of municipal property complex is detrimental to the attainment of target social and economic indicators on the territories. This priority task is complicated by multiple theoretical and methodological aspects of municipal property utilization regulation, which are ill-conceived and require further correction. Furthermore, the application of innovative regulatory mechanisms within the municipal property life cycle require their scientific reasoning and elaboration of scientific recommendations, as well as arrangement of reasonable interaction with multilevel business structures to enhance the utilization efficiency.

\section{Literature Review}

The theoretical aspects of municipal property management are discussed in the works of the following researchers, such as $^{1-6}$ and others.

\footnotetext{
${ }^{*}$ Author for correspondence
} 
The peculiarities of economy management and regulation in regions and municipalities are reflected in research papers of ${ }^{7-9}$ and others.

The theoretical aspects of municipal property utilization efficiency analysis were studied by both foreign and Russian scientists. Here we should mention ${ }^{10-15}$.

The issues of effective municipal property utilization by local government are described in the works of ${ }^{16,17}$.

An important contribution to the development of partnership between governmental institutions and business entities was made by such scientists as ${ }^{18-23}$ and others.

Our earlier studies ${ }^{24}$ dedicated to the regulation of municipal property complex subsystem within the property life cycle, justified the need to create the conditions for effective property use.

\section{Methods}

In the course of study, we applied the general scientific systemic and comparative analysis methods, Delphi method, ranking method, multi-criteria approach and other scientific approaches.

Analyzing the methodological information sources suggests that the methodological approaches to evaluate the municipal property utilization efficiency in some Russian municipalities are oriented towards more effective municipal property disposition, increase of income from the use and optimization of economic regulatory mechanisms. The authors of this paper offered a method to analyze the municipal property utilization efficiency based on a multi-criteria approach. Aggregating specific indexes into groups determines an integrated index, which may be used to evaluate the municipal property utilization efficiency. The evaluation algorithm covers the following stages: Defining the specific indexes, underlying the municipal territory property utilization efficiency and reflecting the specifics thereof; determining the standard values for each efficiency index; calculating the specific index by each criterion and determining the weight coefficients; calculating an aggregate efficiency index; determining an integrated index of municipal property utilization efficiency and interpreting the results.

Application of this approach to analyze the municipal property complex utilization efficiency permitted to determine the integrated efficiency indexes (property potential, financial, social, organizational indexes), which at some property life cycle stages are the indicators showing the local authorities how to take right strategic managerial decisions on municipal property utilization efficiency.

\section{Results}

\subsection{The Peculiarities of Municipal Property Complex}

A crucial component of economic stability and development of any municipality is its property. The analysis of theoretical and methodological approaches to evaluate the municipal property utilization showed that the studies are mainly targeted at certain properties. Despite the diversity of municipal property elements, they form an integral structure, which may be integrated into the property complex, in the authors' opinion. The property belonging to the municipality is traditionally categorized on the following grounds: Ground connection nature (movable and immovable assets), intended and functional use $^{2,10}$. It should be noted that wear rate drastically affects the property serviceability. It leads to technical state change and debasement of particular parameters of the property complex elements. We have extended the classification with a criterion, presented in Figure 1, that is usability (serviceability) of municipal property complex, divided intro the following groups: serviceable, conditionally serviceable and non-serviceable ${ }^{24}$.

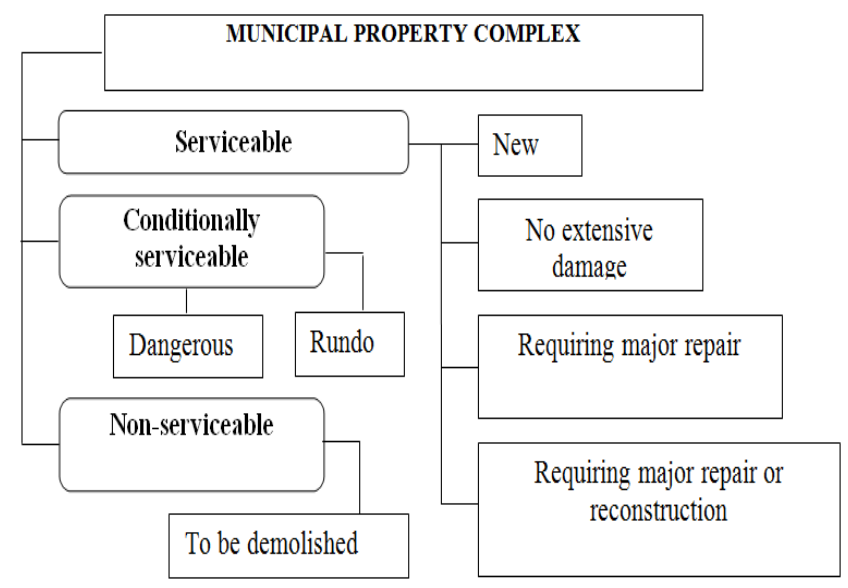

Figure 1. Classification of municipal property complex by serviceability.

Taking into account a discrete role of municipal property, in particular, immovable property, being socially-oriented and profitable, it seems appropriate to focus on the property life cycle stages (acquisition, use 
and disposal). The duration and parameters of each stage largely depend on the factors and conditions contributory for higher or lower utilization efficiency of the municipal property complex subsystems.

Following the common objectives of regional management, including municipal property complex, under conditions of growing social and economic development level of the territory, the economic life of municipal property, i.e., a period of time during which the property is serviceable and may be used to derive the respective revenue, is of particular interest ${ }^{14}$. It is important to note that the economic life expires when the improvements made (reconstruction, modernization etc.) cease to contribute to the property value and, respectively, degrade its serviceability ${ }^{15}$. Therefore, it is advisable to analyze the share of each municipal industry, measure the significance of social, transport and infrastructure facilities, and to determine their real potential in ensuring social and economic welfare of the municipality population.

To select the serviceable property, it is offered to use not only the liquidity period, but also other criteria, which may be regarded both collectively and discretely. We have defined the following criteria as the most relevant: An original or residual cost of property complex; wear coefficient; specific and integrated indexes of utilization efficiency. The municipal property utilization is regulated by fixed property rental rates; available privatization options; grants; application of regional and local tax rates; municipal property trust and pledge. So economic regulation of municipal property utilization makes it possible to maximize the outcomes of its possession, utilization and disposition, which are reflected in local budget replenishment, unemployment reduction, creation of conditions for small and medium business development.

\subsection{The Municipal Property Utilization Efficiency Analysis}

Scientific literature recommends to enhance the property utilization efficiency with managerial intervention based on the following economic regulation principles: goal orientation; preservation; profitability; publicity and others ${ }^{10,22}$. In our opinion, it is wise to focus on continuous value augmentation as one of the basic economic regulation principles for municipal property utilization. It underlines the need to implement the principles of rational use and cooperation between business and state under restricted budgetary resources of the territory, and to determine the most relevant economic regulatory mechanisms.

The analysis of property management practices in multiple Russian regions and municipalities suggests that there are no consistent approaches to evaluate the municipal property complex utilization efficiency. The peculiarities of certain elements thereof are not clear enough, and the diffuse, often delinked, indicator groups are used. Based on the results of this study it is recommended to categorize the indicators by groups, characterizing certain sectors and peculiarities of municipal property utilization, such as: Property potential indicators; financial indicators; social and organizational indicators, permitting to analyze the property utilization efficiency. Depending on the intended use of municipal property, the given list may be expanded with technical, environmental and other indicators.

The property complex utilization efficiency analysis, involving multiple municipalities, performed in the course of this study, revealed many problems related to property misuse and lack of demand for certain elements thereof as well. Concurrently, we noted the reduction in revenue received as a rental charge for property compensated use, accounting for $90 \%$ of the total proceeds in these items, payable to the municipal budget. In addition to the abovementioned problems, the inadequate property utilization, control and accounting are evidenced by a high wear rate of residential and non-residential municipal properties of the territories.

Resolution of property utilization regulation issues is facilitated by elaboration of task-oriented interaction mechanisms between society, municipality, small and medium entrepreneurs. The coordinated interaction between all the parties will permit to meet the objectives of municipal property utilization efficiency improvement, adjust and implement target programs of the territories in the following areas:

- Implementation of target programs aimed at the municipal property utilization efficiency improvement.

- Creation of comfortable and safe conditions at socially relevant facilities, and residential premises.

- Raising the human well-being.

- Improvement of the municipality's investment image. Development of small and medium entrepreneurship within the municipal territory, etc.

To ensure the efficient property utilization on the 
Table 1. The municipal property complex utilization improvement areas

\begin{tabular}{ll}
\hline Area & Measure \\
\hline $\begin{array}{l}\text { 1. Classifying the municipal } \\
\text { property complex.by service- }\end{array}$ & $\begin{array}{l}\text { Specifying the municipal property assets and structure. } \\
\text { ability }\end{array}$ \\
& $\begin{array}{l}\text { Assessing the technical state and wear rate of property. } \\
\text { Determining the property serviceability. } \\
\text { Spotting the causes of low demand for the property. } \\
\text { Listing the municipal property requiring major repair, modernization, reconstruction, etc. } \\
\text { Reducing the number of non-demanded municipal property. }\end{array}$ \\
$\begin{array}{ll}\text { 2. Applying } \\
\text { economic regulatory mecha- } \\
\text { nisms to ensure the demand } \\
\text { for conditionally serviceable } \\
\text { and non-serviceable munici- } \\
\text { pal property. }\end{array}$ & $\begin{array}{l}\text { Attracting potential users of municipal property from amongst small and medium entre- } \\
\text { preneurship. } \\
\text { Attracting private investors to solve the issues of effective municipal property complex } \\
\text { utilization. }\end{array}$
\end{tabular}

share of immovable property, being a part of municipal property complex, and increase the number of companies with majority interest within the municipality. An equally important aspect of municipal property utilization efficiency is serviceability record keeping, as well as the use of property in order to boost the demand for 'conditionally serviceable' and 'non-serviceable' property. The municipal property complex utilization improvement areas and measures are presented in Table 1.

The integrated values obtained in the course of study permit to evaluate the municipal property complex utilization efficiency at a certain life cycle stage that favors the creation and implementation of target municipal programs aimed at education and culture development, and urban planning as well. The recommended measures will enable us to identify and eliminate the causes of ineffective municipal property utilization, and thereupon correct the managerial decisions and economic regulatory mechanisms for the strategic milestones of social and economic municipality development.

\section{Discussion}

One of the recommended regulatory mechanisms for property complex utilization is to build the mutually beneficial relations between the municipal authorities and business entities via Municipal-Private Partnerships (PMPs). In international practice this sort of interaction is referred to as 'Public-Private Partnership' (PPP) $)^{21,25}$. As $\mathrm{EU}$ and US experience shows, there is a growing need for project implementation involving private companies in different business areas. For instance, the construction costs will be reduced therefore. Thus, with the total cost optimization within the interaction process, project success is at average by $10-20 \%$ higher as compared to the alternative business models to the exclusion of entrepreneurs. In general, a buoying factor of PPPs application is that they provide for cost-intensive socially relevant project implementation within the shortest possible time, and higher project success due to private sector involvement.

Partnership with private entrepreneurs in foreign countries features various business models and relations, e.g., power authorization contract with private entrepreneur (USA), mixed economy society (SEM), concessions (France) and others ${ }^{13,18}$. These business models are based on private sector engagement to meet the public needs of the territory. Such cooperation may be introduced within different legislative structures with a wide range of tasks and duties.

The analysis of Russian and foreign experience of partnership creation shows that they may exist in a variety of areas: Transportation industry; public utilities operation; finance; environmental protection; education, etc. Cooperation between local government authorities and private sector via MPP provides for many advantages for the municipality, small and medium entrepreneurship, as well as general socioeconomic development of the territory and better standards and quality of life ${ }^{26}$.

Economic regulation of the municipal property complex utilization via MPP establishment favors additional investments in the municipality's economy (from private investors); Pooling of municipal and private (material, financial, intellectual, research and technology) resources to develop the municipality's economy and social sphere; integration of private sector into social life of the municipality, its involvement in social project implementation by direct participation of entrepreneurs 
in the municipal property construction, utilization and maintenance.

\section{Conclusion}

Improvement of economic regulatory mechanisms for the municipal property complex utilization conditions the social and economic stability, growth and development of regions, in general, and municipalities, in particular.

The municipal property complex as a sophisticated multi-component structure, comprising municipal property located within the municipal territory, having its intended and functional use, aimed to meet the public needs of the territory. Russian and foreign municipal management practices show that the most common economic regulatory mechanisms for property utilization are the following: Standard deductions from profits of municipal companies to the local budget; grants; standard fees for property use; local taxation; rental conditions for municipal property complex; municipal property privatization options; establishment of various publicprivate partnership forms and others.

Economic regulation of property utilization is exercised at different management levels (state, regional and municipal), following the basic and amended principles to encourage optimal combination of material and cost parameters, achieve strategic development objectives both at the municipal and state level.

All of this argues for further studying of economic regulation of the municipal property complex utilization to define the reasonable and efficient corrective measures aimed at territorial development.

\section{References}

1. Knorring VI. Osnovy gosudarstvennogo i munitsipalnogo upravleniia [Foundations of the public and municipal administration]. Moscow: Ekzamen; 2014. [in Russian].

2. Kobilev AG, Kirneev AD, Rudoy VV. Munitsipalnoe upravlenie i sotsialnoe planirovanie $\mathrm{v}$ munitsipalnom hozyastve. [Municipal management and social planning in the municipal sector]. Rostov-na-Donu: Feniks; 2007. [in Russian].

3. Levin, SA. Mestnoe samoupravlenie v federativnykh gosudarstvakh Evropy: Sravnitelno-pravovoe issledovanie. [Local government in the federal states of Europe] [Extended abstract of candidate's thesis]. Moscow; 2007. [in Russian].

4. Marchenko AV. Ekonomika i upravlenie nedvizhimostiyu. [Economics and property management]. Rostov na Donu: Feniks; 2010. [in Russian].
5. Mukhaev RT. Sistema gosudarstvennogo i munitsipalnogo upravleniya. [System of the public and municipal administration]. Moscow: UNITI-DANA; 2010. [in Russian].

6. Shirocov AN. Munitsipalnoe upravlenie. [Municipal management]. Moscow: KnoRus; 2010. [in Russian].

7. Rassel J, Cohn R. Munitsipalnoe obrazovanie "Afanasevskoe" (Arkhangelskaia oblast) [Municipality "Afanasyevskoye» (Arkhangelsk region)] Moscow: Bookvika publishing; 2013.

8. Andronova IV, Plienkina VV, Osinovskaya IV. Prognozirovanie sotsialno-ekonomicheskikh yavleniy. [Forecasting of the social and economic phenomena]. Tyumen: Tyum-SOGU Press; 2008. [in Russian].

9. Fetisov GG. Regionalnaya ekonomika i upravlenie [Regional economy and management]. M: INFRA-M; 2006. [in Russian].

10. Marcvart E. Khozyaystvennaia deiatelnost munitsipalnykh obrazovaniy. [Economic activities of municipalities]. Perm; 2010. [in Russian].

11. O'Salivan A. Ekonomika goroda. [The city's economy]. Moscow: INFRA-M; 2002. [in Russian].

12. Asaul AN. Economica nedvizhimocti. [Real estate economy]. Moscow: Piter; 2013. [in Russian].

13. Varlamov VS. Strategicheskoe partnerstvo v sisteme upravleniia munitsipalnoy sobstvennostiyu. [Strategic partnership in the management of municipal property]. Izhevsk; 2007.

14. Eremin SG. Sovremennye problemy upravleniia gosudarstvennoy i munitsipalnoy sobstvennostiyu [Modern problems of management of the state and municipal ownership]. Moscow: Yustitsinform; 2014. [in Russian].

15. Ivanitskaia IP, Yakovleva AE. Vvedenie v ekonomiku nedvizhimosti. [Introduction to the economy of the real estate]. Moscow: KnoRus; 2010. [in Russian].

16. Kompaniets V, Borovskaia MA, Kazanskaia A Yu. Sotsialno-ekonomicheskoe sostoianie "tipichnykh" munitsipalnykh obrazovaniy [Social and economic condition of "typical" municipalities]. LAP Lambert Academic Publishing; 2012.

17. Gutnik V, Oiken V, Luts F, et al. Teoriia khoziaystvennogo poriadka. "Frayburgskaia shkola" i nemetskiy neoliberalizm [Theory of an economic order. 'Frayburgsky school' and German neoliberalism]. Moscow: Ekonomika; 2002.

18. Eganian A. Investitsii v infrastrukturu. Dengi, proekty, interesy. GCHP, kontsessii, proektnoe finansirovanie [Investments into infrastructure. Money, projects, interests. PPP, concessions, project financing]. Moscow: "Alpina Publisher"; 2015. [in Russian].

19. Ihnatov VH, Butov VI. Zarubezhnyy opyt mestnogo samoupravleniia i rossiyskaya praktika. [Foreign experience of local government and Russian practice]. Moscow: MarT; 2005. [in Russian].

20. Levi AV. Efectivnoe upravlenie munitsipalnoy sobstvennostiyu. [Effective management of municipal property]. Moscow: 2008. [in Russian].

21. Lebediva ML. Frantsuzkaia munitsipalnaia sistema - vozmozhnost primeneniia v sovremennoy Rossii [French 
Russia]. The role of environmental engineering in rural areas in sustainable development of agribusiness: Mezhdunarodnaia nauchno-prakticheskaia konferentsiia. Moscow, FGOU VPO "Moscow State University of Environmental Engineering"; 2007. [in Russian].

22. Parakhina VN, Galiev EV, Ganshina LN. Munitsipalnoe upravlenie. [Municipal management]. Moscow: KNORUS; 2008. [in Russian].

23. Saveleva EA. Ekonomika i upravlevie nedvizhimostiyu [Economy and management by the real estate]. Moscow: Infra-M; 2013. [in Russian].

24. Deberdieva NP. Regulirovanie podsistemy imushchestvennogo kompleksa munitsipalnogo obrazovaniya $\mathrm{v}$ protsesse zhiznennogo tsikla imushchestva. [Control subsystem of the property complex of the municipality during the life cycle of the property]. Innovation in the management of regional and sectoral development. The All-Russian Scien- tific and Practical Conference with the international participation; Tyumen: TyumSOGU. 2012. p. 53-8. [in Russian].

25. Gritsenko EV, Manssen G, Khimelraykh A. Publichno-chastnoe partnerstvo v munitsipalnoy sfere. Germanskiy i Rossiyskiy opyt [Public and private partnership in the municipal sphere. German and Russian experience]. Moscow: "Infrotropik Media"; 2014.

26. Andronova IV, Deberdieva NP. Rol munitsipalno-chastnogo partnerstva $\mathrm{v}$ sotsialno-ekonomichescom razvitii munitsipalnogo obrazovaniya gorodskogo okruga goroda Tumeni. [Role of municipal and private partnership in social and economic development of municipality of the city district of the city of Tyumen]. Social and economic development of the regions of Russia. 2nd International Scientific and Practical Conference; Moscow: MESI. 2012. p. 42-9. [in Russian]. 